Int. J. Dev. Biol. 53: 1179-1191 (2009)

doi: $10.1387 / \mathrm{ijdb} .082811 \mathrm{am}$

\title{
A perspective on the development of Genetics in Spain during the XX Century
}

\author{
ALFONSO MARTINEZ-ARIAS* \\ Department of Genetics, University of Cambridge, Cambridge, UK
}

\begin{abstract}
At the beginning of the XXI Century, Spanish Biology lives a period of unprecedented growth and development. This situation owes much to the stability of the last few years and breaks a pattern in which Science was the activity of a few self-taught individuals working within an indifferent environment. The development of Genetics is a good example of these factors. A long isolated period dating back to the 1500 s was broken at the beginning of the $X X$ Century through the creation of a number of institutions and, in particular the Junta de Ampliacion de Estudios, which created a seed for scientific development and had a significant effect in the area of Genetics. However, the Spanish civil war destroyed this seed and forced a new beginning. Throughout the second half of the century, steady progress, largely driven by individuals formed abroad and returning to Spain with knowledge and methods, has been the basis for the establishment of a scientific ingrastructure from which Spain is making important contributions to modern biology. The person of Antonio Garcia-Bellido has emerged over the last $\mathbf{4 0}$ years as a reference for modern genetics and also as the root of an important, perhaps the only, real school in this area of work.
\end{abstract}

KEY WORDS: genetics, Spain, history, Drosophila, Junta de Ampliacion de Estudios

"Our science will then always be unruly and as such bold and bolshy; it will earn certainty through jumps and not bit by bit; at some point it will get into step with Universal Science to shortly go behind for centuries. Barbaric, mystical and wandering has been, and / fear will be, Spanish Science."

Jose Ortega y Gasset, La Ciencia romántica, El Imparcial 4 Junio 1906

History shows that Spain does not have a scientific tradition, that although it has produced scientists, a few of them outstanding, Spain has not had a Science and that what it had resembling this enterprise came to be in the manner suggested by Ortega y Gasset. This much is true and it is echoed in a number of the pages of this Special Issue. However, that was the past. Nowadays Spain thrives in its Science, particularly in the biological sciences. After decades of contributing to modern Biology through individuals, Institutes of international status flourish in Spain with a mixture of young and experienced researchers. The words of Ortega are a thing of the past. There are two related reasons for this turn of events. The first one is a long period of social and political stability that begins with the death of Franco [Francisco Franco, military general and dictator in Spain from 1830 till his death in 1975] and ushers a good dose of liberalism at all levels. Such a period has no parallel in Spanish history. The second, a by-product of the first, is the development of Institutions with adequate support, benefiting from strategic planning and the experience of researchers educated abroad. Spain has always had the human potential and the possibilities to reach its current level, but Spain has always been a hostage of its history and its rulers in a negative way. The history of Genetics in Spain, the central theme of this article, illustrates this well and provides a good example of the strengths and weaknesses of the system. It also shows how continuity is the essence of scientific development and how social and political stability can condition scientific progress.

Before starting, a word of caution and an apology. I am not a

Abbreviations used in this paper: CBM, Centro de Biología Molecular; CNIO, Centro Nacional de Investigaciones Oncológicas; CSIC, Centro Superior de Investigaciones Científicas; JAE, Junta de Ampliacion de Estudios.

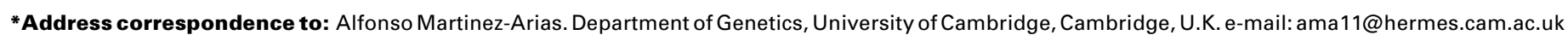


historian and do not pretend this to be more than a personal view of the history of Genetics in Spain. I also want to make sure that the notion of continuity and its need for proper scientific development comes across. For this reason I shall dive into some ancient Spanish history to build the narrative. The apology is to those involved in many aspects of Genetics not covered in depth here, particularly plant Genetics, and who will appreciate an emphasis in Drosophila. While there is a bit of personal bias in this, it is also a fact that the genetics of Drosophila occupies an important part of the history of spanish genetics and it has been the branch in which Spain has made significant contributions to the book of Science. In my view, this last reason alone, rarely appreciated in Spain, justifies the emphasis. However, as it is clear in the account, this is also a reflection of the facts. For more detailed and professional accounts of the history of Genetics in Spain at the beginning of the $X X$ century, the interested reader should consult R. Alvarez Pelaez (2007), S Pinar (1999, 2002a) and particularly the work of Milagros Candela (2003) which represents a most comprehensive attempt to document the origins and development of spanish genetics.

\section{The seeds (1859-1909)}

In the face of the current success and its roots, largely laid down in the 1970s, it would be very easy to forget the origins of genetic research in Spain, the false starts, the fog that covers up the transition between the XIX and the XX century. It would be easy to draw a line in the 1960s and quickly move on, to a period we can relate to and in which Spain has become, finally, an integral part of the global enterprise known as Science. However, this would be unfair on the pioneers, on the individuals who used their curiosity and their excitement for Biology to try to forge a contribution to a different Spain. Without a Neanderthal man, no Beethoven, nor Goya; without Miescher, no Watson and Crick. There is another reason for reviewing the roots of Genetics in Spain and this is that having a long look reveals a pattern that has delayed the development of spanish Science and therefore recounting it, might allow us to draw some lessons.

Spain missed out on the crucial scientific developments of the XVII, XVIII and also much of the XIX centuries (for details and accounts, see Garcia Camarero eds 1970). There are social and political reasons for this. At the end of the XVI century, Spain was a country run down by a mismanaged adventure in America, with a peasant based population and a heavy anti-cultural mood fuelled by a collusion of church and government. The product of this cocktail was an isolated country in which only the curiosity of individuals maintained some contact with progress. The contrast with the late medieval period in which Spain was central to Western culture, is stark. The achievements of the judeo-arab period and of the school of translators in Toledo became buried with the entry of Ferdinand and Isabella in Granada in 1492. Few episodes epitomize this best than the decision, implemented by Cardenal Cisneros, to burn many arab and jewish libraries and manuscripts, particularly in southern Spain. From this on and until the XIX century, Spain remained shrouded in a cultural vacuum and became a breeding ground for the kind of scientist Ortega refers above. Nevertheless, slowly small glimpses of scientific interest emerge at the institutional level. In the Natural Sciences, for example, the Museum of Natural History in Madrid is founded by Charles III in 1771 as Royal Cabinet of Natural Sciences. During the XIX century it attracts much of the activity in various branches of the sciences with a focus on Geology, Zoology and Botany. The Museum was going to play a key role in the attempts to develop the science of Genetics in Spain even though for most of the XIX century it keeps a low and uninteresting profile.

The publication of "The origin of species" by C Darwin in 1859 is a major landmark in the history of Biology and the reception of the evolutionary theories in Spain a good example of the start and stop pattern that characterizes this period (Pelayo, 1996; Blazquez Paniagua, 2008). The first translation of the Origin into spanish appears in 1877, but before then hints of interest in darwinism find their expression during the revolutionary period of la Gloriosa (1868-1874). At this time there is a rise in the teaching and discussion of darwinism and evolutionary ideas, though always with a highly social rather than scientific content. The discussion is brought to an end with the "Restauración" that follows the Revolution. In a manner that will repeat itself fifty years later with dire consequences, those who had made illustrated statements about Darwin and Evolution during the Revolution paid with removal from their jobs, prohibition to teach and in some instances, prison. An example of how bad the situation was can be gauged from the boast of the dean of the University of Santiago who proudly announced that his library did not contain any books by Darwin or Haeckel (Nuñez, 1997). However, time heals and it also allows forgetfulness. Slowly, throughout the 1880 s, academics are readmitted to their posts. During the last part of the XIX century Darwinian concepts appear again in universities and in this regard it is important to mention the work of Odon de Buén, whose teachings in Barcelona led to his suspension in 1895 (http:/ /www.ieo.es/biografia_odon.htm).

A most important development of this period is the establishment of the Institucion Libre de Enseñanza by F. Giner de los Rios, allowing a more liberal learning environment which would benefit the import of scientific ideas and methods from abroad. Another event of this period, this one of some significance for the biological sciences in Spain, is the establishment in 1886 of La Estación Marítima de Zoología y Botánica Experimental de Santander, on the model of that of Naples and with an interest in Natural History (http://servicios.eldiariomontanes.es/patrimonio/ museos/mus16.htm).

By the end of the XIX century Spain has foci of activity in the Natural Sciences. Darwinism, because of its social implications, always figures in these developments and many pro-darwinists come out of the closets, slowly, always within a very conservative atmosphere (Núñez, 1997). In 1909 two acts were programmed to celebrate the $50^{\text {th }}$ anniversary of the publication of "the Origin of Species", one in Valencia and one in Lorca. Largely led by students, these acts demonstrate the eagerness and interest that existed at time for this topic (Blazquez Paniagua, F. 2008). However, these celebrations fell into the hands of social, political and religious agents which, not for the first nor the last time, overshadowed the scientific interest that drove the events in the first place.

As ever, Science is the endeavour of a few, individually driven by their curiosity. This was not the exception in Spain at this time and in the mold of the statement of Ortega y Gasset the end of the XIX century has the towering figure of Santiago Ramón y Cajal. There is no question about the significance of this extraordinary 

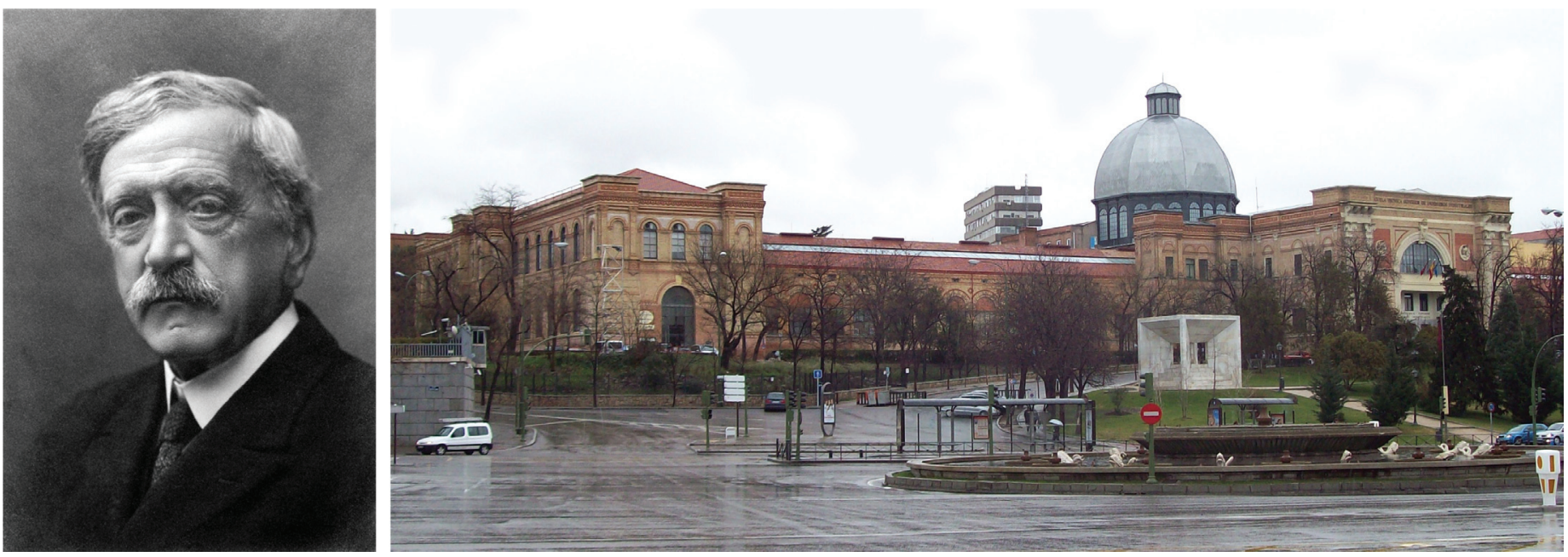

Fig. 1. Ignacio Bolívar y Urrutia (1850-1944) and present view of the Palacio de las Artes e Industrias (Fernando de la Torriente, 1881-1886). The building is shared at present by the National Museum of Natural Sciences and The Technical School of Industrial Engineering of the Polytechnic University of Madrid, Spain.

individual, nor of his contributions to Science, but I am not sure that he is a good example of much that is of use to collective programmes of research. The overpraising of his figure and achievements, inadvertedly, has often overshadowed smaller but effective scientific activities in Spain. One should hasten to add that Cajal himself was aware of this and that in some of his writing he highlighted the right way of doing things, though often betrayed his origins and saw Spain as inferior to other more developed countries.

\section{The pioneers (1909-1936): the Silver Era}

Thus, at the beginning of the XX century Spain harbours a seed for the development of the Biological sciences, particularly in the form of an awareness of Darwin, a Museum of Natural History and the Marine Station of Santander. However, much of the focus of research is on Botany and Zoology with little interest in experimental questions of embryology and heredity that were central issues in the rest of Europe.

In 1907, in a rare moment of vision, the government of the time decides to establish the Junta de Ampliación de Estudios (JAE), an institution inspired in the philosophy of the Instituición Libre de Enseñanza and born with the explicit aim to endow Spain with a mechanism for scientific and technological development (Calandre Hoenigsfeld, 2008). Under the headship of Ramón y Cajal, it provided means to send young people abroad to acquire knowledge and technology and to bring it back to Spain. An example of its success is that in its 30 years of existence it provided over 2000 fellowships to work abroad. The programme of the JAE also led to the creation of a national infrastructure for the return of the scientists and the rapid graft and development of the acquired knowledge. This objective led to the creation in 1910 of the Instituto de Ciencias Físico-Naturales that provided an umbrella organization for all of the sciences.

A most important figure of this period in the biological sciences, and second only to Cajal in scientific reputation in Spain, is Ignacio Bolívar (1850-1944) (Fig. 1). An entomologist by education and Catedrático of Zoology since 1877, Bolívar participated in the foundation of the Marine Station in Santander, and in 1901 became director of the Museum of Natural History overseeing its move, in 1912, to its current location in the Paseo de la Castellana. This move allowed him a reorganization of the structure of the Museum and in 1911 to establish the Laboratory of Biology which would become a cradle of genetic research.

The entry of the XX century is a crucial moment for Biology. The rediscovery of Mendel's work and the quick development of Genetics as the solution to the riddle of Heredity acts as a launching pad for an interesting piece of history (Olby, 1966; Carlson, 2004). The work of Morgan with the fruit fly is, without a doubt, the most important event of this period (Carlson, 2004; Martinez Arias, 2008) and Spain followed this work closely. An important reason for this was the appointment of Antonio de Zulueta y Escolano (1885-1971) to direct the Laboratory of Biology of the Museum of Natural History (Pinar 2002a). Born in Barcelona, Zulueta had accumulated a wealth of experience in the Natural Sciences through his work in the marine station of Santander, and through studies funded by the JAE in Berlin, with R. Goldschmidt, and in Paris. In Madrid he began to teach the new ideas running through Biology, with an emphasis in Genetics and translating many books, in particular Darwin's "El origen de las especies" (Madrid, Espasa-Calpe 1921) and Morgan's "Evolucion y mendelismo" (Madrid, Espasa-Calpe 1921). In 1918 he initiated genetic studies, largely with the beetle Phytodecta variabilis with which he made significant contributions to the genetics of the $Y$ chromosome by providing some of the first observations that it contains genes (Zulueta, 1925; and see discussions in Pinar 2002a; Candela, 2003 and Pinar and Ayala, 2003). He was well connected and informed and corresponded with the best geneticists of his time. In 1930 he visited Morgan in Caltech with a fellowship from the JAE and worked with Bridges in Drosophila (Pinar and Ayala, 2003; http://www.ucm.es/info/antilia/asignatura/ practicas/trabajos_historia/genetica.htm). In 1932 Zulueta became the first Catedrático of Genetics in Spain (Cátedra from the Patronato Conde de Cartagena), holding the position first in the Museum of Natural History, and from 1934, in the Facultad de Ciencias of Madrid. As most spanish scientists of the time, 
Zulueta made major contributions from the position of a modest scientific environment and with meagre resources. However, possibly his most important work is not as a researcher but as a mentor and an educator.

A most important contribution of Zulueta, lies on his disciples, in particular José Fernández Nonídez (1892-1947) who obtained a doctorate with Zulueta studying aspects of the biology of the chromosomes of sperm in insects, an important topic in those days (Pinar 2002b, Argüelles, 2006). Having obtained his degree, Nonídez spent time in Cambridge (UK), with Doncaster and Punnet, through a scholarship of the JAE, and after a short stay in Zurich, in 1917 arrived in New York in the laboratories of EB Wilson and TH Morgan where he worked until 1920. During this stay he learnt the new concepts and experimental techniques that laid down modern Genetics and upon his return to Madrid in 1920 at the suggestion of Zulueta, he taught a course to introduce Drosophila genetics in Spain. It is also likely that the first strains of Drosophilawere imported by Nonidez in 1920 from the laboratory of Morgan (Pinar, 2003). His stay in Spain was brief and he returned to the USA in 1920 where, aside of fleeting trips to Spain, he would develop the rest of his career. In 1922, he published "La herencia mendeliana: introducción al estudio de la Genética" Madrid, Espasa-Calpe 1922, which was the result of the course he taught in the Museum in 1920. Progressively he abandoned the study of genetics and from 1935 he devoted his time to the study of anatomy and histology, always in the US until a premature death in 1947.

The relationship of Nonídez with Morgan and Wilson gives him a particular place in spanish Biology, but there were other young biologists associated with the Laboratorio de Biologia and Zulueta. Fernando Galán (1908-1999), who would remain the main disciple of Zulueta beyond the Civil war and would be important in keeping the feeble but significant influence alive. Other disciples of Zulueta were Manuel Bordas, a cytogeneticts, Gimena Fernández de la Vega who is the first human geneticist in Spain, Nicolas Rubio, Antonio Menacho and Edouard Reichenow (Candela, 2003).

A most important figure in a parallel branch of genetics, not linked directly to Zulueta, is Cruz Angel Gallastegui y Unamuno (1891-1960), an excellent example of the successes of the JAE who can be considered as the father of plant genetics in Spain. He spent time in the USA visiting and learning from the pioneers of plant genetics, most significantly from DF Jones and upon his return to Spain in 1921, he established the Misión biológica de Galicia, as part of the great national Institute of Sciences and dedicated to the all important matter of plant genetics and breeding. Here he developed some of the first corn hybrids which were going to play an important role in the development of modern agriculture (Candela, 2003).

At this time, the efforts of the JAE were being rewarded, and foreign scientists were regular visitors of spanish institutions. Some notable figures, for example A Einstein and E Schrodinger, had been offered positions in Spain and considered them for a while (Moore, 1994). The interactions of Zulueta with the Kaiser Wilhem Institute in Berlin, attracted the interest of Käte Pariser, (1893-1953), a german jewish biologist who studied with Richard Goldschmidt and who in 1931 became interested in studying speciation in axolotls in the North of Spain. Events in Germany led her top leave and she landed in the Museum in Madrid in 1933 under the protection of Zulueta. Here she worked, in the basement of the Museum until 1936 when she had to move on because of the political developments.

Thus it is not difficult to see that in the 1930s there was a modest but promising scientific infrastructure in Spain. In the context of Biology the School of Ramón y Cajal as well as the efforts of Bolívar and Zulueta in the Museum were beginning to pay dividends. The JAE was achieving its objectives, people were coming back bringing knowledge and in the context of this work, there was a nucleus of geneticists in Madrid, well connected to the rest of the world and with promise. This period has often been called the Silver period of Spanish science, perhaps because there has never been a golden one.

\section{The civil war and its consequences (1936-1939)}

This Silver Period was always unstable and developed, as it is often the case in Spain, against a complex political and social backdrop (Otero Carvajal, 2000). The Civil war was not a surprise but rather the inevitable conclusion of the trends of the time (Brennan, 1943; Madariaga, 1958). It brought trouble in all fronts and led to the destruction of all the educational and cultural work that had been laid down over the previous 30 years. However, Science continued during the war. Zulueta pursued his interests in the Museum in Madrid and there is an account of $\mathrm{H}$. Muller working with him in the cellars of the Museum in 1937 (Carlson, 1981). Muller had come to Spain from the Soviet Union, where he had been helping establish genetics. In Spain he was setting up a blood transfusion unit on the republican side (Carlson, 1981).

The end of the war and the triumph of general Franco brought a stop to the developments that had been initiated by the JAE (Calandre Hoenigsfeld, 2008; Otero Carvajal, 2001). Here there are echoes of La Gloriosa and La Restauracion, except that in 1939 there was much more to destroy than in the late 1870s. Also the destruction was more severe, as stern repressive actions were taken against anybody who had anything to do with the Republican government (Garcia Camarero, 1978). For this reason, Science suffered badly, as most scientists were, in one way or another, affiliated to republican institutions. Many of them emigrated. Focusing on the protagonists of this story, Bolívar with his son, also a biologist, to Mexico, others, like Nonidez, already in the US, did not return. Zulueta, stayed in Spain but was removed from his research and teaching positions for political reaons. Most of those who decided to stay would have to keep a low profile over the years and do their job quietly.

It is easy to underestimate the destruction brought about by the Civil War and, most significantly, its consequences for spanish Science. In 1936 Genetics did not have a figure like Cajal, but there was a group of dedicated and well connected individuals who had established a valuable structure for its development in terms of teaching and research. The war destroyed this and the repression that was to follow, killed it. The return was not going to be easy and I would like to suggest a reason for this through a comparison with Germany. The two world wars, but the second in particular, had a devastating effect on Germany, a country culturally much more advanced than Spain but upon which a bigger catastrophe ensued. And yet, despite difficulties, Science recovered. It is true that there was an injection of capital, particularly US based capital, but the main reason, I believe, is the depth of its 
roots which helped much of the financial input that it received in the 1950s. Science needs roots and while these were very deep in Germany by the beginning of the XX century, they were feeble and weak in Spain. Thus, after the war, time was needed for new roots to develop, for new ideas to graft, a start from the very beginning. The conditions and prospects were not good and the single most important consequence of the war was that Spain relapsed into its shell. Sleepy, inward looking, scornful of foreigners. For a second time, the possibility of development is shattered by political and social reasons. All the efforts of the JAE were absorbed into a new Institution, the Consejo Superior de Investigaciones Cientificas (CSIC, National Research Council), and the trend to come was made clear by Jose lbañez, its first president in the inaugural meeting:

"Queremos una ciencia católica. Liquidamos, por tanto, en esta hora, todas las herejías científicas que secaron y agostaron los cauces de nuestra genialidad nacional y nos sumieron en la atonía y la decadencia. [..] Nuestra ciencia actual, en conexión con la que en los siglos pasados nos definió como nación y como imperio, quiere ser ante todo católica". (cited in Elias, 2000)

"We want a catholic science. We therefore disband, as of now, all the scientific heresies which dried and squeezed the rivers of our national genius and led us to numbness and decadence (...) Our present science should be connected with that of former centuries which defined us as a Nation and as an Empire and wants to be first and foremost catholic"

\section{The pioneers: back to the beginning, third time lucky (1939-1975)}

The speech of lbañez made it clear that spanish science was going to be built on the essence of an Imperial Catholic Spain. Once more the only chance for survival was the recipe of Ortega: Science would have to emerge from the ashes as a result of individual actions. It is difficult, from the comfort of the present day, to grasp how hard this period was socially and also, of course, scientifically (Otero Carvajal, 2001). One can gauge the social aspects from some novels of the time and certainly from the vast amount of literature that has appeared on the subject since the death of Franco. Scientifically it is more difficult. One can talk to the individuals who lived through that time, but there is a novel, which became a cult in the 1970s, that provides a glimpse of what the life of an aspiring scientist must have been at the time. It is not centered in science, but "Tiempo de Silencio" by Luís Martín Santos, relates the trials and tribulations of a young cancer researcher through Madrid in the aftermath of the war in all its bleakness.

Despite the speech of Ibañez, Spain was not the Soviet Union and there was no Lyssenko that would determine what could or could not be done or thought. Science, underfunded, ignored and more often than not left to its own devices in the context of the CSIC, began to find its footing. In the realm of Genetics, the school of Zulueta was kept alive by by $F$. Galán, now a catedratico of Biology in Salamanca. Zulueta himself was asked to resume his teaching in 1946, and this he did until 1952, when he was substituted by the cytogeneticist Eugenio Ortiz. Gallastegui resumed his activities at the head of the station in Galicia and became an important focus for the all important development of plant genetics which became established as a discipline in the context of the School of Agricultural Engineers, with a strong focus in plant breeding. He developed his studies here until 1960, when he was substituted by Miguel Boceta, who would develop the center of cerealicultura in Madrid and later on by Miguel Odriozola, whi develop a parallel and important interest in animal breeding (Candela, 2003). This and some cytogenetics, was the main thread upon which Genetics continued to be taught and practices in Spain.

The importance of plant genetics in the maintenance of a genetic tradition in Spain should not be underestimated and, particularly through the teachings of Gallastegui and Galan, became a solid platform for some of the developments that would follow. The School of agricultural engineers was an important focus of this influence and, in particular, the activities of Enrique Sánchez-Monge who had been taught by Gallastegui and Boceta and held a professorship of Genetics from 1960. However proper Catedras (Spanish professorships) of Genetics were not visible in the University until 1963 when there was a call for the first Catedras since the war for Madrid, Barcelona and Granada. Five scientists contested the three positions available: Enrique Sánchez-Monge, Antonio Prevosti, a catalan with a deep and self taught interest in evolutionary aspects of genetics with a focus in Drosophila, Eugenio Ortiz, director of the laboratory of Genetics of the CSIC since 1956, Amadeo Sañudo, a plant geneticist in the vein of Gallastegui and with an interest in potato genetics and, finally, Fernando Galán, Zulueta's disciple (Lacadena, 2000; Candela, 2003). Sanchez Monge obtained one of the positions and established himself in Madrid. The second one in Barcelona went to Antonio Prevosti, where he established the first formal department of Genetics in a University in Spain in 1963/64 and the one in Granada was won by Eugenio Ortiz who, however, did not want to move there and remained in the CSIC. The position was readvertised in 1967 and then went to Amadeo Sañudo.

\section{Molecular genetics}

The period between the 50 s and the 70 s is an important time in the history of Genetics. After the golden age of Morgan and his students, and the development of transmission Genetics, the burning issue is to unravel the molecular nature of the gene (Judson, 1979). The interaction with Biochemistry and a change of focus from complex eukaryotes to prokaryotes are important elements of progress. Spain did not make any contributions to this period with one distant and serendipitous exception: Severo Ochoa (1905-1993), a biochemist who had left Spain in 1936. After a series of positions at different Institutions in Germany and Great Britain, he settled in the USA at New York University, and became a US citizen in 1956. In 1955 while studying the way cells utilize glucose to generate ATP, just by chance found an enzyme capable of synthesizing RNA in vitro which allowed him and his team to contribute to the definition of the elements of the genetic code by synthesizing specific RNA polymers. For this he received the Nobel Prize in 1959 together with A. Kornberg.

Severo Ochoa was not a geneticist, and his serendipitous discovery notwithstanding, most of his work, certainly the one that bears on this article, was done abroad. However, his connections with Spain led him to act in the 60s as a center for some of the young people that were leaving Spain at the time in search of knowledge and which were to return with new ideas and enter- 
prises. The visit of Eladio Viñuela (1937-1999) and Margarita Salas between 1964 and 1967 acted as an important catalyst in the rebirth of Genetics and Biology in Spain because they imported the techniques and concepts of phage biology and molecular genetics. Margarita Salas, would become Profesor of Molecular Genetics in la Facultad de Químicas de la Universidad Complutense and Eladio Viñuela, would contribute to the settlement of research in Molecular Biology in Spain (Avila, 1999 and see below).

\section{Antonio García-Bellido}

One of the most important challenges of Biology is to understand the generation of organisms from single cells. During the last decades of the XX century, Genetics made very significant contributions towards the resolution of this problem. Spain has played an important role in this enterprise through the figure of Antonio Garcia Bellido, a geneticist from Madrid. He exhibits much of the self taught and self-developed character of Ramon $y$ Cajal and has no less influence in his field than Ramon y Cajal had in the area of Neurobiology. A few years ago, A. Ghysen (1998) edited a volume of the Int J Dev Biolas a tribute to the Science of Garcia-Bellido and the present volume contains an extensive interview in which he looks at his life (Ghysen, 2009). Nevertheless the extent and influence of his contribution to Genetics and to Spanish Biology in particular, demand a consideration of his work here.

Antonio García-Bellido (Fig. 2) was born in Madrid in 1936. Having developed an interest in the mechanisms that generate organisms, he decided that Genetics held the key to the solution of this problem (as he once told me: it was obvious!). After a thesis under Eugenio Ortiz in the CSIC, he saw that the solution to the problem of the development of an organism required a link between genes and cells which did not exist at the time. This hunch led him, through a short stay in Cambridge (UK) with V. Wigglesworth and a longer and very productive time in Zürich with E. Hadorn, to Caltech in California (USA). Here under the tutelage of Ed Lewis, he began to put together the pieces for an analysis of development in terms of genes and cells using Drosophila as a workhorse (Garcia Bellido, 1998) and unleashed the power of

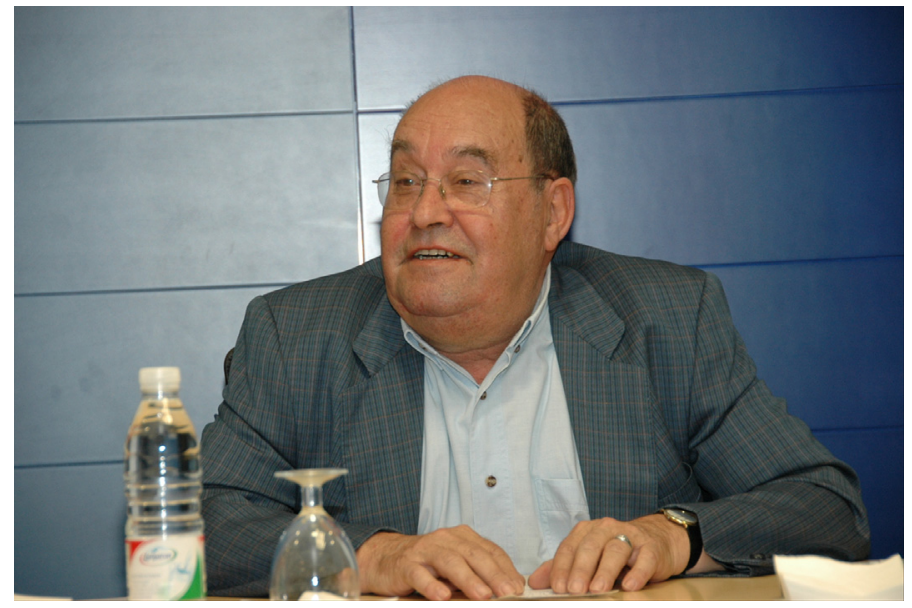

Fig. 2. Antonio García-Bellido in an event to pay tribute to the career of Juan Modolell (Madrid, 2006). the genetic analysis of developmental processes by means of genetic mosaics (Ghysen, 2009). Upon his return to Madrid in 1968 , he set to develop a very ambitious programme of research which bore its first fruits in the discovery of developmental compartments, units of lineage which define realms of gene activity and expression and which are building blocks of tissues in many organisms (Garcia Bellido et al., 1973). At this time, GarcíaBellido had three very talented students, his first three students, Pedro Ripoll, Ginés Morata and Pedro Santamaría, who played their own role in the development of the analysis of developmental processes through genetic mosaics.

In the early 1970s, Spain was still fairly isolated and the laboratory of García-Bellido was little known outside the small circles that had an interest in his techniques and in the genetics of Drosophila. However, this was about to change in 1973 with the visit to Madrid of Peter Lawrence, a British developmental biologist with an interest in pattern formation. As a result of this visit, Lawrence, who had made observations compatible with the existence of developmental compartments in another insect, Oncopeltus, adopted much of the approach of the Madrid geneticists (Lawrence, 1998). Later, together with F. Crick, he wrote a very influential article (Crick and Lawrence, 1975) alerting the scientific community to what was happening in Madrid, in particular to the significance of compartments and the possibilities of clonal analysis as a tool of discovery. Shortly afterwards, working together with Ginés Morata, Lawrence made major and significant contributions to the linkage between genes and cell lineages (Lawrence and Morata, 1994).

Madrid soon became a small Mecca for anybody with an interest in developmental genetics and García-Bellido began to exert a global influence by creating a framework which later was going to become central to the molecular understanding of developmental events. This influence was implemented through a series of informal meetings, the first of which took place in 1976 in the village of Rascafría, in the mountains outside Madrid (Fig. 3 ). In these meetings, a small group of scientists with a common interest in genetic approaches to developmental problems and who used Drosophila as a system, would get together to discuss informally results and ideas. This group would grow and change through the years and in the early 1980s was a most interesting forum of discussion and exchange of results which moved around Germany, France, Great Britain and would often go back to Rascafría. The influence of this group on the development of many young scientists is undisputable. The group of people can be called the "Madrid School". The basic techniques and concepts from the Madrid School were adapted and modified with the introduction of molecular biology (Xu and Rubin, 1993), but the influence remained. Today genetic mosaics as a way to link genes, cells and organisms, is a standard tool of the trade yielding insights and results both in vertebrates and invertebrates.

The interests of García-Bellido are well anchored in questions of developmental biology and focused on cellular approaches (see interview with A Ghysen, 2009). During the 1980s, he pursued the problem of what sets the boundaries of developmental systems in terms of growth and pattern, issues that have been a constant of his scientific interests. This work led him to the notion of Entelechia (García-Bellido and García-Bellido, 1998) through which he has formulated some of the more fundamental issues of pattern formation and regulation, in particular when and how does 


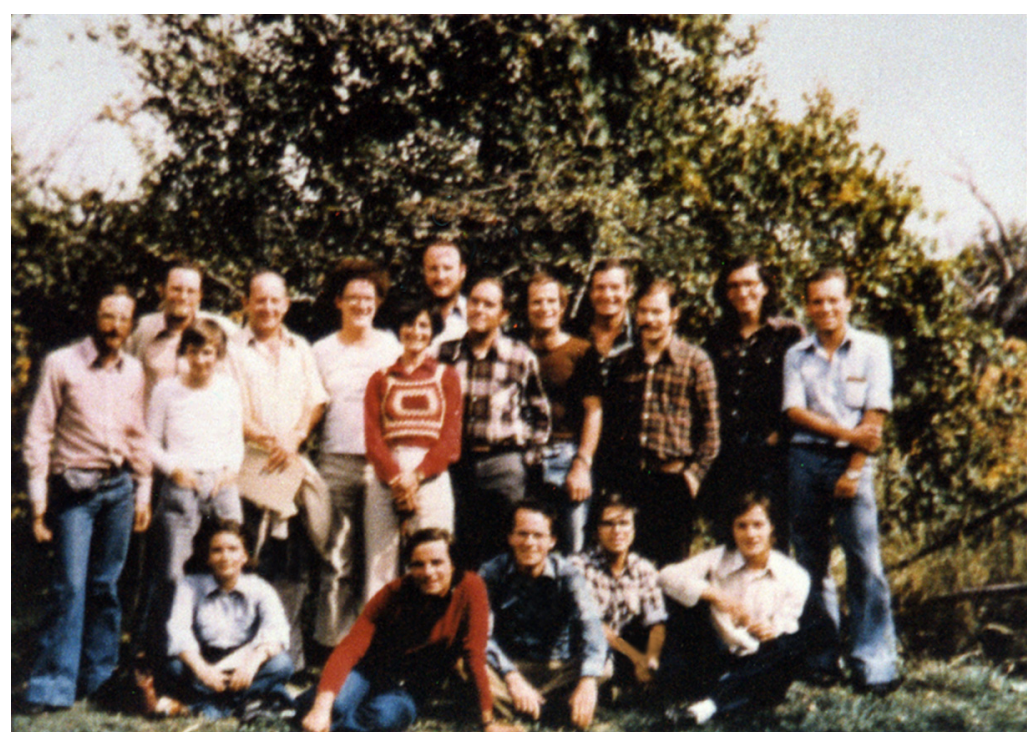

Fig. 3. Photograph of the attendees to the first Rascafria meeting in the Sierra of Madrid (1976). From left to right (standing): Pedro Ripoll, Pedro Santamaria, Pat Simpson, Eliezer Lifchytz, Robert Whittle, Maria Paz Capdevilla, Alberto Ferrus, Antonio Garcia Bellido, Peter Lawrence, Rolf Nothiger, Tom Kornberg, Francisco Rey, Francisco Wandosell; (sitting) Fiorella LoSchiavo, Glauco Tocchini-Valentini, Jose Antonio Campos Ortega, Gines Morata and Jaime Moscoso. Photograph courtesy of Rolf Nothiger.

an organism know that it is done. His interests also expand to evolutionary biology where he has made some interesting excursions. However, while his contributions to Genetics and to Biology at large are formidable, he has made a major contribution through his students. Unlike Cajal or Zulueta, his work and influence have been allowed to develop and now we have a fourth generation of students that have developed under his lineage (see Appendices 1 and 3).

\section{Outside Madrid}

It has been suggested that in the period between the 50 s and the 80s, Spain was a desert for Genetics with an oasis centered in the group of García-Bellido in Madrid (Baguña, 2009). Unless one was interested in plant genetics, there is some truth to this view, but it is also true that Genetics was taught and worked upon in other places, and that these smaller activities had an influence on some individuals. Thus as mentioned above, Antonio Prevosti created in Barcelona the first proper Department of Genetics at a Spanish University after the Civil war, and developed it with a very strong line of population and evolutionary genetics. Prevosti created his own school which sprouted in Valencia with his disciples Jose Luis Mensua y Rosa de Frutos. and contributed to create a critical mass of population genetics. Other disciples of Prevosti included Antonio Fontdevila, Eduardo Petitpierre, Rosa Gonzalez Duarte, Monserrat Aguade, Luis Serra and significantly, Jaume Baguña. During the $60 \mathrm{~s}$, genetics began to be developed with other organisms: in Sevilla, Enrique Cerdá Olmedo who had studied with M. Delbruck, worked on the genetics of fungi and brought new molecular concepts and techniques from his stay in the US, and in Salamanca, Julio Rodríguez Villanueva, encouraged the parallel development of bacterial and fungal genetics.

Aside of these centers, the lack of coordination and information across places and the parochial nature of research in Genetics in Spain during the 60s and the 70s, leads some people to seek their fortunes abroad. Two figures are particularly important in this category: Jose A Campos Ortega and Francisco J Ayala.

JA Campos Ortega (1940-2004) (Rodrigues, 2005, Marco Cuellar, 2006 and see article by Hertel and Knust, 2009) played a most important role in creating a bridge between classical embryology and Genetics thus closing an important gap which had not been addressed by García-Bellido. He carried out most of his research in Germany, learnt Genetics by himself but had strong links with the german school of classical insect embryology. His major contributions were in the area of the development of the nervous system in Drosophilaand a few years before his untimely death he had begun to work on the developmental genetics of the zebrafish as a model for vertebrate studies (Hertel and Knust). Campos Ortega developed some connections with García-Bellido and as a consequence played host to some, but not many, young Spanish researchers. Particularly important amongst these was Fernando Jiménez (1950-1999), a student of Margarita Salas, who reached Campos Ortega through Garcia Bellido. Jiménez died very young but not before making important contributions to developmental genetics (Campos Ortega, 1999). Furthermore, at the time of his death he had just moved from Madrid to Alicante pioneering a movement out of Madrid that was going to become very important in the late 1990s.

Franciso $\mathrm{J}$ Ayala, born in Madrid and nationalized US citizen is one of the most important contemporary figures in the field of Evolutionary Biology. Following interactions and discussions with Zulueta and Galán in Madrid at the early stages of his career, he went to the US to work with T. Dobzhanski. He never returned to Spain, and has become a big influence in the genetic analysis of the evolutionary processes.

The Sociedad española de Genetica was founded in 1972, as a recognition of the critical mass of rearchers in Genetics in Spain. Its first president was Antonio Prevosti and vice president Enrique Sanchez Monge. Ever since it has been a center and coordinator of the activities of research in Spain.

\section{The modern era: CBM and CNIO}

In the 1970s and the 1980s Genetics diversified. The arrival of molecular biology and its combination with classical genetics, allowed tackling not just problems of developmental biology but also shed a very fresh perspective on questions of cancer and disease. Molecular Biology came to Spain initially, as mentioned above, through the interactions of young researchers with Severo Ochoa and later through the actions of other researchers doing postdoctoral stays, principally in the US.

In the early 1970s, the research unit of the CSIC in the Calle Velázquez in Madrid, is an interesting hub where the seeds of the current situation germinate. Eladio Viñuela, Margarita Salas, Antonio García-Bellido and David Vázquez, another Spanish biochemist/molecular biologist formed in the UK, occupy labs close to one another and young biologists have a chance to thrive 
in a buzzing environment. In 1975 these interactions catalyze the foundation of the Centro de Biología Molecular «Severo Ochoa» (CBMSO aka CBM) in Madrid, through the fusion of the Instituto Universitario de Biología Molecular of the Autonomous University, led by Federico Mayor Zaragoza, and three institutes from the CSIC led by Eladio Viñuela, David Vázquez and Antonio García Bellido. The CBMSO would prove an important couldron of science through the 80 s and the 90 s as well as a cradle for young scientists who, after their $\mathrm{PhD}$, proceed to go abroad to expand their horizons.

Many of these developments take place after the death of Franco in 1975, an event which gets Spain out of its long slumber. Institutions begin to change and a modern era is ushered at the educational and social level. Moreover, for the first time this is done without social upheavals and with a will to build and to develop. There is no question that Science in general and Genetics in particular, benefit from this pace of development. Thus, through the late 80 s and 90 s, many of those that went abroad come back and to create the critical mass for the exciting present sitiuation. A significant landmark in this process is the return to Spain of Mariano Barbacid, a molecular geneticist by training and whose team in the US was one of the first to isolate a human oncogene in 1982. He returned to Madrid in 1998 to develop the Centro Nacional de Investigaciones Oncológicas (CNIO), now one of the leading centers for Cancer studies in Europe. In the last few years, the examples set by CBMSO and CNIO have been followed and institutes with strong genetic roots flourish everywhere. The Center for Genomic Regulation (CRG) and the Institut of Recerca Biomedica (IRB) in Barcelona, Center for Cardiovascular Research (CNIC) in Madrid, Biogune in Bilbao, Principle Felipe in Valencia and Centro Andaluz of Developmental Biology (CABD) in Sevilla are important engines of the modern Biology in Spain. Even more importantly, foreign scientists now go to Spain to work. It is probably not by chance that Genetics is an area of predominant interest in these successes.

The phrase of Ortega with which I opened these considerations does not apply anymore to Spanish science and the continuity of the last forty years ensures that it will never be needed again. Spain has had an opportunity to settle its roots and in doing so has begun to develop its potential. In the last ten years a large input of money and the efforts of many scientists who, after a period abroad, have come back to develop what they have learnt, has transformed Spain from a country that exports biologists to one that imports them. As the Internet takes hold of our lives and our culture and makes the world flat, Spanish biology is emerging as one of the European hubs and one that has much to contribute to the global project.

\section{Acknowledgements}

I want to thank Antonio García-Bellido for setting me this task. Pursuing it has taught me a great deal about Biology in our country and has provided an interesting perspective on the roots of its current health in Spain. Also to him and to Jaume Baguña, Nicole Gorfinkiel, Peter Lawrence, Gines Morata, Juan Modolell, Silvia Muñoz and Jose F. de Celis many thanks for information, comments and discussions on many issues of this manuscript. I also want to point out that the massive amount of information that lies in the Internet made the research for this article easy, in particular with regard to biographies and facts about many of the individuals mentioned here (not many that is true). The reader can easily check this by her/him self. I have to give special thanks to Milagros
Candela for a brief but intense, informative and interesting cup of coffee in which she filled many holes of an earlier version and lent me for a few days her book "Los origenes de la genética en España". This is an important piece of work which rescues (like this article tries to do) an important part of our humble butproud scientific history. It is a pity that this volume has been printed only once in a limited edition for members of the Spanish Society of Genetics. It should be reprinted for a wider readership. In the end it is a pity that Spain does not appreciate that its scientific past harbours more than Ramón y Cajal. Finally, my thanks to Juan Aréchaga for being patient and persistent and for providing some important touches to the final manuscript, particularly Fig. 1.

\section{References}

ALVAREZ PELAEZ, R. (2007). La genetica y la junta para la ampliacion de estudios e investigaciones cientificas. Asclepio. Revista de la Historia de la Medicina y de la Ciencia 59: 163-180

ARGÜELLES J.C. (2006). El Profesor Jose Fernandez-Nonidez (1892-1947) y la Universidad de Murcia. Anales de Biologia 28: 129-136.

AVILA J. (1999). Eladio Viñuela (1937-1999) the molecular biology pioneer in Spain. Int Microbiol. 2: 119-120.

BAGUÑA J. (2009). A history of Evo Devo research in Spain. Int J Dev Biol. 53: 1205-1217. (doi: 10.1387/ijdb.072427jb)

BLAZQUEZ PANIAGIA F. (2008). Notas sobre el debate evolucionista en España, 1900-1936; http://www.cervantesvirtual.com/FichaAutor.htm/?Ref $=15070$ Biblioteca Virtual Miguel de Cervantes, Edición digital a partir de Revista de Hispanismo Filosófico, núm. 12 (2007)).

BRENNAN G. (1943) The Spanish labyrinth: An Account of the Social and Political Background of the Civil War. Cambridge University Press.

CALANDRE HOENIGSFELD C. (2008). La Junta de ampliacion de estudios republicana frentepopulista, represaliada por el franquismo y olvidada por la transicion y la democracia. $H A O L$ 16: 7-16

CAMPOS ORTEGA, J.A. (1999) Closing remarks. In "Of genes, molecules and neurons: in memoriam of Fernando Jimenez". Instituto de Neurociencias UMHCSIC.

CANDELA M. (2003) Los orígenes de la genética en España. Sociedad cultural de conmemoraciones culturales. Madrid.

CARLSON E.A. (2004). Mendel's legacy. Cold Spring Harbour Press.

CARLSON E.A. (1981). Genes, Radiation and Society. The life and work of H Muller. Cornell University Press.

CRICK F. H. AND LAWRENCE P. A. (1975). Compartments and polyclones in insect development. Science 189: 340-7.

ELIAS C. (2000) in El Mundo; Ciencia y Sociedad, 15 October 2000.

GARCIA BELLIDO A. (1998). The engrailed story. Genetics 148: 539-544.

GARCIA BELLIDO A.C. AND GARCIA BELLIDO A. (1998) Cell proliferation in the attainment of constant sizes and shapes: the Entelechia model. Int J Dev Biol. 42: 353-362

GARCIA-BELLIDO A, RIPOLL P, MORATA G. (1973) Developmental compartmentalisation of the wing disk of Drosophila. Nat New Biol. 245: 251 253.

GARCIA CAMARERO E.(1970). La polemica de la Ciencia en España. Alianza editorial,. Madrid.

GARCIA CAMARERO E. (1978) La ciencia española en el exilio. In Elexilio español de 1939. Vol. 5 pp 191-243. JL Abellan editor. Taurus ed.

GHYSEN A. (2009). Ontogeny of an adventurous mind: the origin of Antonio GarciaBellido's contributions to developmental genetics. Int J Dev Biol. 53: 1277-1290. (doi: 10.1387/ijdb.072384ag)

JUDSON H.F. (1979) The eighth day of creation. Simon and Schuster. New York

KNUST E. and HERTEL R. (2009). José-Antonio Campos-Ortega (1940-2004) and his scientific work - a personal perspective. Int J Dev Biol. 53: 1193-1203. (doi: 10.1387/ijdb.072480ek)

LACADENA J.R. (2000). Profesor Fernando Galan Gutierrez, in memoriam, los prineraos tiempos de la Genetica en España. Boletin de la Sociedad Española 
de Genetica. 14: 7-12.

LAWRENCE P.A. (1998) «Turning Points» A crew of patches. Current Biology 8: R71-72.

LAWRENCE P. AND MORATA G. (1994) Homeobox genes: their function in Drosophila segmentation and pattern formation. Cel/78:181-189.

MADARIAGA S, (1958) Spain, a modern history. New York: Frederick A. Praeger MARCO CUELLAR R. (2006). The scientific roots of Jose A Campos Ortega, a german neurobiologist born in Spain. Dev Dyn 235: 855-860.

MARTINEZ ARIAS A. (2008) Drosophila melanogaster and the development of biology in the 20th century. Methods Mol Biol. 420: 1-25.

MOORE W. (1994) A life of Erwin Schoroedinger. Cambridge University Press. Cambridge.

NÚÑEZ D. (1997). "Estudio preliminar". El darwinismo en España. Revista de Hispanismo Filosófico, 2: 31-36.

OLBY R.C. (1966) Origins of mendelism. Schocken books. New York.

OTERO CARVAJAL L.E. (2000). La Ciencia en España. Un balance del siglo XX. Cuadernos de Historia Contemporánea. Universidad Complutense 22: 183224.

OTERO CARVAJAL L.E. (2001). La destruccion de la ciencia en España. Las consecuencias del triunfo military de la España franquista. Historia $y$ comunicacion social. 6: 149-186.

PELAYO F. (1996) El darwinismo en España, Anales de/ seminario de la historia de la filosofia 13: 263-284.

PINAR S. (1999) La introduccion de la genetica en España durante el primer tercio del siglo XX. Llull: Revista de la Sociedad Española de Historia de las Ciencias $y$ de las Técnicas 22: 453-473.

PINAR S. (2002a) The Emergence of Modern Genetics in Spain and the Effects of the Spanish Civil War (1936-1939) on Its Development J History of Biology35: 111-148.

PINAR S. (2002b). The watershed histology of Jose Fernandez Nonidez and the introduction of Mendelian chromosome theory in Spain. Asclepio 54: 3-18.

PINAR S. (2003) Jose Fernandez Nonidez, introduccion en España de la teoria cromosomica de la herencia. In "Los orígenes de la genética en España". Candela, M. editora. Sociedad cultural de conmemoraciones culturales. Madrid.

PINAR S. AND AYALA F. (2003) Antonio de Zulueta y los origenes de la genetica en España. In "Los orígenes de la genética en España". Candela, M. editora. Sociedad cultural de conmemoraciones culturales. Madrid.

RODRIGUES V. (2005). Prescience and critical thought: the life and science of José Campos-Ortega. J Genet. 84: 217-222.

TEIXIDO F., BIÓLOGOS ESPAÑOLES, http://www.citologica.org/fteixido/ default.asp?ld=2\&Fd=2 - Antonio de Zulueta Fernandéz (1885-1971)

XU, T. AND RUBIN, G.M. (1993) Analysis of genetic mosaics in developing and adult Drosophila tissues. Development 117: 1223-1237.

ZULUETA, A. (1925) La herencia ligada al sexo en el coleoptero Phytodecta variabilis (OL). EOS Revista española de entomologia. Tomo I, pp 203-233.

\section{Appendix 1}

\section{The School of García-Bellido}

The laboratory of García-Bellido has been active in Madrid since 1968 and, in the absence of social upheaval and with the continuity that this affords, has allowed several generations of scientists to develop from its roots. Besides the first three students already mentioned (G Morata, P. Ripoll and P Santamaría), the list is long and at the risk of offending people for not mentioning all of them (though all are in Appendix 3), I want to highlight a few because of their contributions to the development of modern genetics and because their current interests highlight how much the school of Madrid has been a breeding ground of excellent and diverse science.

Amongst the direct students of García-Bellido there are Alberto Ferrús (who developed interests in neurobiology and is currently working in Madrid), Juan Botas (currently in Houston, USA, using Drosophila as a model system for human disease) and in a later era, an interesting group that coincided in their time in the lab with Juan Pablo Couso (currently in the University of Sussex, UK with an interest in pattern formation and EvoDevo), Jose Felix de Celis (back at the CBMSO in Madrid, Spain after a long time in Cambridge, UK continuing the traditions of the Madrid School into the molecular era), James Castelli (at the CABD in Seville, Spain pursuing aspects of Cell Biology in Drosophila) and Marcos González Gaitán (now at the University of Geneva, Switzerland after many years in Germany and doing imaginative and interesting work at the boundary of Biophysics, Cell Biology and Genetics). Within a newer generation is Marco Milán (currently in PCB, Barcelona working on the cell biology of compartments) and Cassandra Exteavour (currently at Harvard in Boston, USA, with a deep interest in EvoDevo). Antonio García-Bellido also attracted a few postdocs, amidst which there is Alicia Hidalgo, currently in Birmingham (UK), who is now interested in neurobiology but who did important work on the cellular biology of developmental compartments. This list of selected disciples and their current interests highlights not only the quality of the School but also the range of interests that inspired.

But for a School to merit its name, the students have to give rise to a new students, to a third generation and this is most clearly the case here (see Appendix 3). Of the three first students, each produced scientific offspring. Pedro Santamaría moved to Paris, France where he developed a career with an interest in mosaics. Pedro Ripoll continued his deep interest in Genetics developing Drosophila as a model for the study of mitosis and meiosis and one of his students, Cayetano González (currently at the IRB in Barcelona, Spain after many years in the UK and Germany), is one of the leading figures in the field of chromosome mechanics and cancer biology. Ginés Morata developed his interests in compartments and homeotic genes and has produced a number of important students amidst which are Ernesto Sánchez Herrero (currently in Madrid, Spain, with an interest in the cell biology of homeotic genes), Jordi Casanova (in the IRB in Barcelona, using Drosophilaas a system to study cell biology) and Acaimo González Reyes (currently at the CABD in Sevilla, Spain, following studies he had initiated in Cambridge, UK, on oogenesis and its cell biology). All of these in turn have their own students which, in many cases, have developed already their own independent careers extending the García-Bellido influence into a fourth generation. Thus Fernando Casares (CABD, Sevilla, Spain), a student of Ernesto Sánchez Herrero continues the line of developmental genetics characteristic of the School.

In addition to what can be considered direct descent from García-Bellido, there are others who can be considered, as G 




Fig. 4. From left to right: Juan Modolell, Alfonso Martinez Arias, Antonio Garcia Bellido, Gines Morata and Peter Lawrence during a tribute to Juan Modolell in Madrid in 2006. Photograph courtesy of Juan Modolell.

Morata has put it, 'assimilated' into the School. Thus, one could consider Jaume Baguña, Lucas Sánchez or the unfortunately deceased Fernando Jiménez and to a certain degree Peter Lawrence. However, there is one person who, though assimilated, has a place of his own and has given rise to a school of his own. In 1979, Juan Modolell (Fig. 4), a biochemist who by the 1970s had devoted his career to the study of antibiotics and protein biosynthesis in bacteria within the CSIC, discussed with García-Bellido the possibility of working in developmental genetics following his interest in new horizons (Modolell and Campuzano, 1998 The achaete-scute complex as an integrative device. Int. J. Dev. Biol. 42: 275-282.). García-Bellido suggested he took on the Achaete-Scute complex, a group of genes involved in the patterning and development of the sensory organs of the fly in which he had been interested for many years. From 1979 onwards Modolell organized a group around this complex, imported into Spain many of the methods of modern large genome molecular biology and assembled a group of students with which he unraveled the biology of Achaete-Scute. It would not be unfair to say that the studies of his group have enlightened the field of pattern formation and provided important insights into the links between genetics and molecular biology that have been used by many groups and systems. Juan Modolell has created his own school with most of his students, some of which received the influence of GarcíaBellido who was next door, developing their own groups and interests, clearly following patterns of the Madrid School (Appendix 3). Thus, as an example of the breadth and the influence of the Madrid School, amidst the students of Juan Modolell, Sonsoles Campuzano is working at the CBMSO in Madrid on Drosophila territorial specification and cell biology, Pilar Cubas works in plant patterning in Madrid, Mar Ruiz Gómez (also in the CBMSO studies the biology of muscle development), María Jesús García García (in Cornell University, USA after many years in New York, works in the early development of the mouse) and José Luís Gómez Skarmeta (currently in CABD in Seville, Spain, who initiated work on Xenopus and zebra fish when still with Juan Modolell).

The influence of García-Bellido, very direct in the cases mentioned above, has been enormous in the field of developmental genetics. In Drosophila as clonal analysis has been a central tool for the analysis of the role of genes in development and their function at the cellular level. Beyond Drosophila because the ideas and techniques used in the fly for the analysis of gene function have permeated other systems and nobody will question the strengths and insights of clonal analysis in the study of vertebrate development. The recent discovery of compartments, almost sensu Drosophila, in the vertebrate limb is an interesting corollary of this (Arques CG, Doohan R, Sharpe J, Torres M. (2007) Cell tracing reveals a dorsoventral lineage restriction plane in the mouse limb bud mesenchyme. Development 134 3713-3722). It is probably not surprising that the analysis was made by Miguel Torres, whose lineage can be traced to the School of Madrid.

\section{Appendix 2}

\section{A personal note}

In some form or manner I am part of this story. I have worked on the developmental genetics of Drosophila melanogasterfor a long time and, through events, places and people, I have been privileged to know all of the contemporary protagonists of this story and have followed developments from close range. On the other hand, like Campos Ortega and Ayala, I left Spain early and had to discover much abroad which I should have discovered at home. Perhaps because my story is typical of a generation, it might be useful to recount the roundabout way in which I came to work with Drosophila.

During my schooling, I developed a curiosity about Evolution and Development. The reason for this was more than anything else the mystery in which these topics were shrouded. In the 1960s, I learnt about Evolution in Religious studies, as something dangerous and perverse. As for Development in the context of a conservative church run educational system, certain topics that required sex were always a problem in the Natural Science class, and Embryology (developmental biology did not exist as such) was one of them. Still, the masses of cells that became organisms in the pages of Natural History textbooks attracted my attention. It was probably the tabu and the mystery that led me in 1972 to study Biology as my undergraduate subject.

In the early 1970s, Franco's regime was in its last gasps and the Spanish University was more a place of political strife than one of learning. In the 1960s, the Franco regime had enabled cheap undergraduate education for everybody without thinking much about what would happen after people got a degree. As a consequence, universities were full of students who, at that time, were mostly involved in social and political discussions. These were interesting times and one had to make an effort to keep scientific curiosity afloat in a sea of political unrest and cries for 
much needed social change. For the most part, in those days one learnt rather than was taught. In Madrid, an exception to this pattern was provided in the second and third years of the Licenciatura (undergraduate degree, which used to take five years) by the departments of Biochemistry (headed by A. Martin Municio) and Genetics (headed by J.R. Lacadena). They had some organization and had engaged in actual teaching using a young faculty with an interest in the subject and, in some cases, experience abroad. Biochemistry and Genetics were the courses in which we learnt the basics. It was not a very stimulating kind of learning, but it was sound and I (like others) owe a huge amount to the foundations laid by these courses. Most important, the regime still cared about whether we read Marx, or Neruda or Alberti, but by then did not worry about our reading Darwin, Heisenberg or, curiously, Monod. It was these readings, and in particular Monod's Chance and Necessity, in the context of the lectures in Genetics and Biochemistry, that made me begin to think about Biology in a broad sense. And so in the last two years of my degree, I sought stimulus by taking some lectures in Chemistry, as by then I had given up on learning any Biology from the standard courses of the curriculum. It was through these lectures that I developed an interest in the physical understanding of biological processes. Having obtained my degree with an undergraduate thesis under the tutelage of a very anglophile Antonio Ribera in the department of Biochemistry, I followed my father's advice to leave Spain and, at the second time of asking, I obtained a Fullbright fellowship to go to study in the USA at the University of Chicago.

The isolation of Spain and the general boredomness of the Biological Sciences had led me to develop an interest in classical Biophysics and the notion that one could solve the problems of Developmental Biology by applying the Physical Sciences to biological problems. This was a very naïve view derived more from isolation and lack of perspective than from a well thought argument. It would be fair to say that like most of my classmates I was scientifically lost and the political excitement of the years on either side of the death of Franco certainly had something to answer for in the many distractions we experienced. Shortly before going to the USA, I heard about García-Bellido and tried to see what he was up to. Lacadena had taught us classical genetics, and this in the most scholastic manner so, at the time, I could not place García-Bellido's work into a context. In any event, by then it was too late and I was bound for Chicago where I arrived in 1978 at the height of the discussions about recombinant DNA. There, with context and good teachers, after dabbling with Biophysics and modelling of biological systems for a year, I was to learn what Biology was about and, surprisingly to discover the power of Genetics. In the end, I did a PhD on molecular genetics in Saccharomyces cereviasiaeand made an effort to read as much Genetics and classical Developmental Biology (more embryology really) as I could. I learnt about the ongoing work on the genetics of $C$. elegansand Drosophila, and heard about García-Bellido more than I had in Spain. The marriage between molecular and classical genetics to solve the problems of development was on its way and I saw that this was the way forward to answer the questions I took with me from Spain. During my trips back home, I got to know Juan Modolell who was starting work on achate/scute and our conversations helped me link the molecular biology I was learning in the US with the developmental biology I had always been interested in.

I have always seen my PhD as something a bit accidental, but it did give me the time and the space to think, to read and to watch. It also taught me molecular genetics, as it was being developed, and in this manner gave me the ability to use its language and technology. It was in Chicago, particularly through some guest lectures given by the Italian molecular biologist Glauco Tocchini-Valentini, that I learnt about Peter Lawrence and decided to do a postdoc with him in Cambridge. Working first with Peter and with Michael Akam and later with Michael Bate, I continued my learning which led me to many and interesting years of Drosophila developmental genetics. It also allowed me to link with the Madrid School, with which Peter had and has many tight links. So, finally, like many others of my generation, I found the way to where I wanted to go but I had to go abroad to find it. I was lucky. Today I am glad that Spain is so different and that the younger generations can find much at home and go abroad to expand their horizons rather than to find new worlds. 
Direct Lineage

Pedro Ripoll (M1)

Ginés Morata (M1)

Pedro Santamaría (G)

Alberto Ferrús (M2)

M. Paz Capdevila (†)

Jaime Moscoso (M)

Juan Botas $(\mathrm{H})$

Luis García-Alonso (A)

Fernando Diaz Benjumea (M1)

Jose F. de Celis (M1)

Marcos Gonzalez-Gaitan (Ge)

Juan Pablo Couso (Br)

Jaime Castelli-Gair (S)

Julian Garcia (?)

Marco Milan (B)

Francisco Cifuentes (SF)

Pedro Fernández-Funez (Ga)

Antonio Baonza (M1)

Cassandra Exteavour ( $\mathrm{Ha})$

Luis Alberto Baena (Lo)

\section{Potsdocs}

Jose L Micol (A)

David Gubb (Bi)

Manuel Mari Beffa (Ma)

Alicia Hidalgo (Bgh)

Enrique Martín-Blanco (B)

Alvaro Glavic (Sa)

Rosa Barrio (Bi)

\section{Secondary lineage}

Cayetano Gonzalez, (B)

Jose Casal (C)

Mar Carmena (E)

Ernesto Sánchez-Herrero (M1)

Fernando Casares (S)

Beatriz Estrada (S)

Jordi Casanova (B)

Marta Llimargas (B)

Marc Furriols (B)

Gerardo Gimenez (B)

Ana Busturia, (M1)

Ana Macias

Acaimo Gonzalez (S)

Sergio Gonzalez-Crespo (B)

Natalia Azpiazu (B)

Soraya Pélaz (B)

Antonio Martinez-Laborda (A)

Manuel Calleja (M1)

Eduardo Moreno (M4)

Julio Barbas (M2), Jose L de la Pompa (M3), Inmaculada Canal (M1)

\section{Appendix 3}

\section{Antonio Garcia Bellido lineage as of 2006}

This lineage is based on one created by Gines Morata in 2006, completed with assistance of Jose Felix de Celis and Juan Modolell. It is most complete in the first generation but only partially complete in the second and third generations. It is representative and gives a very good idea of the dispersion and variation generated by the School. The notion of assimilative induction refers to the fact that these people, though not direct students of Garcia Bellido, fell under his influence and learnt about Drosophila developmental genetics with him. Most of the scientists in the secondary lineage (F2) have their own students (F3) now, even though only some of them are mentioned here. And many of the F3 have an F4 but the list of the F3 and F4s would be too long and only a few are included; apologies to those not included which, nevertheless are acknowledged in their lineages. The letters in parenthesis indicate the location of the individual in 2006. A: Alicante; B: Barcelona; Bgh: Birmingham, UK; Bi: Bilbao; Br: Brighton, UK; C: Cambridge, UK; Co: Cornell (USA); E: Edinburgh, UK; G: Gyff sur Yvette (France); Ga: Galveston (USA); Ge: Geneva (Switzerland); H: Houston, USA; Ha: Harvard (USA); Lo: London (UK); M: Madrid with M1: CBMSO; M2: Instituto Cajal; M3:CNB/CNIC; M4: CNIO; Ma, Malaga; S: Sevilla; Sa: Santiago de Chile (Chile); SF: San Francisco (USA); V: Valencia;? current position unknown; †, deceased. 
Assimilative Induction

Juan Modolell (M1)

Sonsoles Campuzano (M1),

Maria Dominguez (A)

Susana Romani (Lo)

Sol Sotillos (S)

Analisa Letizia (B)

Carlos Cabrera ( $t)$

Laura Carramolinos (M)

Pilar Cubas (M3)

Jose L Gomez-Skarmeta (S)

Mar Ruiz (M1)

Ruth Diez del Corral (M2)

Isabel Rodriguez (M1)

Joaquín Culí (M1)

Maria Jesus Garcia (Co)

Joaquin de Navascues (C)

Florencia Cavodeassi (Lo)

Luís M. Escudero (C)

Eugenia Villa-Cuesta (USA)

Joaquín de Navascués $(C)$

Fernando Jimenez ( $\dagger$ )

Lola Martin Bermudo (S)

Ana Carmena (A)

Lucas Sanchez (M2)

Miguel Torres (M3)

Jaume Baguñá (B)

Monserrat Corominas (B),

Florenci Serras (B)

Isabel Guerrero (M1)

Javier Capdevila (M4),

Jose L Mullor (V)

Carlos Torroja (C)

Nicole Gorfinkiel (C)

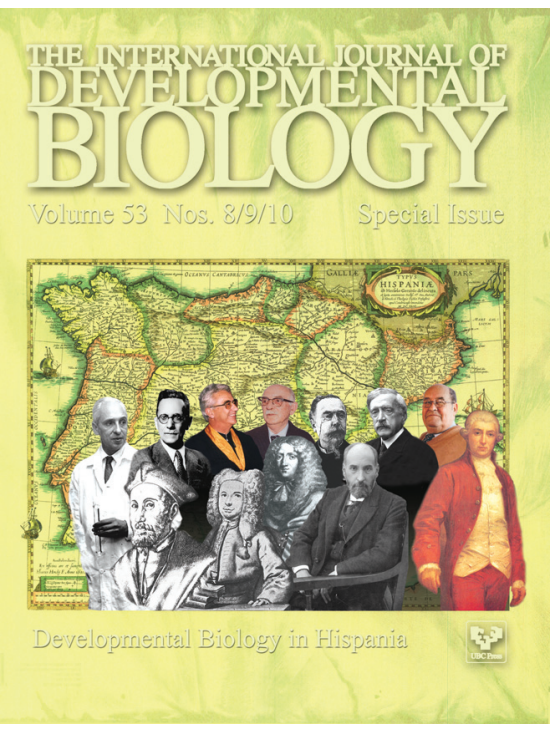




\section{Further Related Reading, published previously in the Int. J. Dev. Biol.}

See our recent Special Issue Epigenetics \& Development edited by Saadi Khochbin and Stefan Nonchev at: http://www.ijdb.ehu.es/web/contents.php?vol=53\&issue=2-3

See Special Issue Pattern Formation edited by Michael K. Richardson and Cheng-Ming Chuong at: http://www.ijdb.ehu.es/web/contents.php?vol=53\&issue=5-6

Iberia: from fable to the bench

Fernando Casares

Int. J. Dev. Biol. (2009) 53: 1269-1271 (doi: 10.1387/ijdb.072461fc)

Plant Developmental Biology in Spain: from the origins to our days and prospects for the future

José-Pío Beltrán

Int. J. Dev. Biol. (2009) 53: 1219-1234 (doi: 10.1387/ijdb.072456jb)

Ontogeny of an adventurous mind: the origin of Antonio García-Bellido's contributions to developmental genetics

Alain Ghysen

Int. J. Dev. Biol. (2009) 53: 1277-1290 (doi: 10.1387/ijdb.072384ag)

A history of Evo-Devo research in Spain

Jaume Baguñà

Int. J. Dev. Biol. (2009) 53: 1205-1217 (doi: 10.1387/ijdb.072427jb)

Apoptosis in Drosophila: compensatory proliferation and undead cells

Francisco A. Martín, Ainhoa Peréz-Garijo and Ginés Morata

Int. J. Dev. Biol. (2009) 53: 1341-1347 (doi: 10.1387/ijdb.072447fm)

1st Joint Meeting of the British and Spanish Developmental Biology Societies

Alicia Hidalgo and Lola Martin-Bermudo

Int. J. Dev. Biol. (2009) 53: 443-446

5th Congress of the Spanish Society of Developmental Biology

Jaume Baguñà

Int. J. Dev. Biol. (2007) 51: 91-96

Cell proliferation in the attainment of constant sizes and shapes: the Entelechia model. A C García-Bellido and A García-Bellido Int. J. Dev. Biol. (1998) 42: 353-362

Interactions between Wingless and Notch during the assignment of cell fates in Drosophila.

A Martinez Arias

Int. J. Dev. Biol. (1998) 42: 325-333

The achaete-scute complex as an integrating device.

$J$ Modolell and S Campuzano

Int. J. Dev. Biol. (1998) 42: 275-282

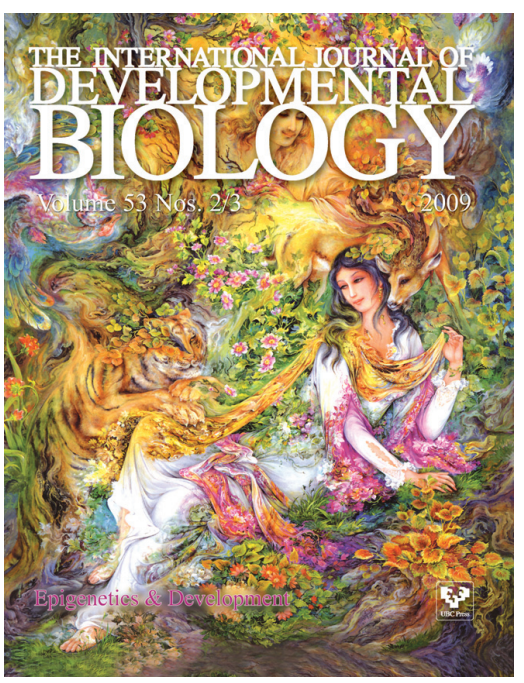

5 yr ISI Impact Factor $(2008)=3.271$

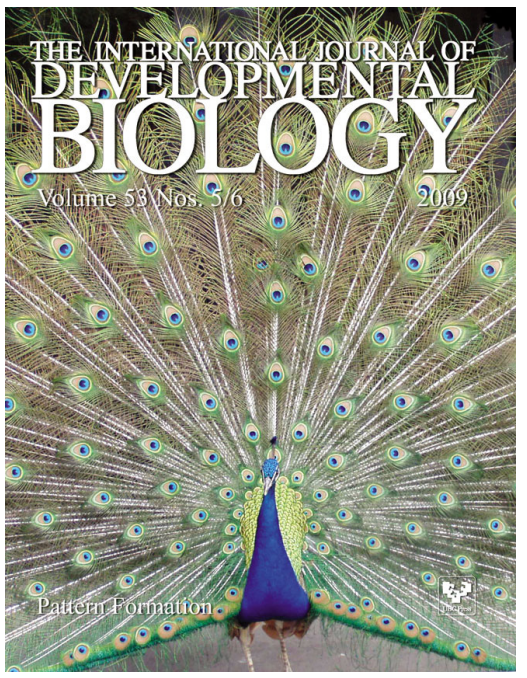

